\title{
Effects of 6 times daily milking during early versus full lactation of Holstein cows on milk production and blood metabolites
}

\author{
M. Eslamizad, M. Dehghan-Banadaky, ${ }^{1}$ K. Rezayazdi, and M. Moradi-Shahrbabak \\ Department of Animal Science, Campus of Agriculture and Natural Resources, University of Tehran, Karaj, Iran
}

\begin{abstract}
An experiment was conducted to determine the effects of different milking frequencies on entire lactation production performance in Holstein cows. One hundred twenty Holstein cows were assigned to 3 milking treatments (35 multiparous and 5 primiparous cows in each): 1) milking 6 times daily for the entire lactation $(6 \times)$; 2) milking 6 times daily for the first $90 \mathrm{~d}$ in milk (DIM) and switching to 3 times daily milking afterward $(6 \times-3 \times)$; and 3$)$ milking 3 times daily for the entire lactation $(3 \times)$. Milk yield was recorded every other day during the first 60 DIM and on 2 consecutive days per week subsequently. Cows were weighed and scored for their body condition immediately after parturition and monthly afterward. Blood and milk samples were taken from each cow on 30,60,90,120,150,210, and 270 DIM, with an additional blood sampling on 15 DIM. Milk and fat corrected milk yield was greater for $6 \times$ and $6 \times-3 \times$ cows than for $3 \times$ cows $(36.82,37.32$, and $36.1,36.75$ versus $34.56,35.33 \mathrm{~kg} / \mathrm{d}$, respectively) during the experimental period. Milk fat and lactose percentage were not different among treatments, but milk protein was lower in $6 \times$ cows than in $6 \times-3 \times$ and $3 \times$ cows. Blood glucose concentration was higher and blood nonesterified fatty acids and $\beta$-hydroxybutyrate concentration were lower in $3 \times$ cows than in $6 \times$ and $6 \times-3 \times$ cows during early lactation. Dry matter intake was greater in $6 \times$ cows than in $6 \times-3 \times$ and $3 \times$ cows (23.05, 22.58, and $22.45 \mathrm{~kg} / \mathrm{d}$, respectively). The $3 \times$ cows began to gain weight earlier than the $6 \times$ and $6 \times-$ $3 \times$ cows, but there was no difference among groups for BW change regarding the entire experimental period. These results indicate that increasing milking frequency to 6 times daily increases milk yield only during early lactation and that there are no advantages of milking 6 times daily compared with 3 times daily during the mid and late lactation periods. Given the results of this study and the economical aspects of production,
\end{abstract}

\footnotetext{
Received January 24, 2010.

Accepted May 3, 2010.

${ }^{1}$ Corresponding author: dehghanb@can.ut.ac.ir
}

milking 6 times daily until 90 DIM and subsequently switching to milking 3 times daily is preferred.

Key words: milking frequency, milk production, blood metabolite

\section{INTRODUCTION}

The dairy industry must produce milk efficiently to survive economically (Blevins et al., 2006). Frequent milking (3 or more times daily) of dairy cows has emerged as an effective management tool for dairy farmers to increase milk production efficiency (Wall and McFadden, 2008). In most experiments where the effects of increased milking frequency (IMF) on milk production have been measured, IMF was initiated at the beginning and continued for the entire lactation period (DePeters et al., 1985); in other experiments (Poole, 1982; Bar-Peled et al., 1995), the effects of targeted periods of IMF during a specific stage of lactation have been evaluated. Increased milking frequency increased milk production (Smith et al., 2002; Hale et al., 2003), and in some cases (Bar-peled et al., 1995; Hale et al., 2003) but not in all cases (Pearson et al., 1979), milk production remained increased for a period after the treatment was terminated, thereby exhibiting a carryover effect of early lactation IMF on milk yield (MY) during the later lactation period.

Although it has been shown that IMF during early lactation does increase MY, timing IMF initiation and the duration of IMF to obtain a significant carry-over effect remain to be investigated (Wall and McFadden, 2008). Furthermore, only a few studies (Bar-Peled et al., 1995; Dahl et al., 2004; VanBaale et al., 2005) have increased milking frequency to 6 times daily and only for a short period in early lactation. The aim of the present study was to evaluate the effects of milking 6 times daily versus 3 times daily in the initial $90 \mathrm{~d}$ of lactation and in the entire lactation on MY and blood metabolites of Holstein dairy cows.

MATERIALS AND METHODS

\section{Cows and Treatments}

This experiment was carried out at Bijin Dairy Farm (Tehran, Iran). One hundred twenty Holstein cows were 
assigned to 3 treatment groups (35 multiparous and 5 primiparous in each) at calving and housed in free stall barns with access to exercise lots. Treatments were 1 ) milking 6 times daily for the entire lactation $(6 \times) ; 2)$ milking 6 times daily for the first 90 DIM and 3 times daily afterward $(6 \times-3 \times)$; and 3$)$ milking 3 times daily for the entire lactation $(3 \times)$. The experimental period started from calving of each cow and ended with drying off. Of 40 cows in the $6 \times$ treatment group, 5 were in first lactation, 12 were in second lactation, and 23 were in third or more lactation. The respective numbers for $6 \times-3 \times$ and $3 \times$ treatments were 6,16 , and 18 and 5 , 14, and 21. Cows of different groups were located the same distance from milking parlor. Milking times were 0230, 0630, 1030, 1430, 1830, and $2230 \mathrm{~h}$ for $6 \times$ cows and 0200,1000 , and $1800 \mathrm{~h}$ for $3 \times$ cows. All cows were fed the same TMR for ad libitum intake $(1.73 \mathrm{Mcal}$ of $\mathrm{NE}_{\mathrm{L}} / \mathrm{kg}$ of DM, $18 \% \mathrm{CP}, 30.6 \% \mathrm{NDF}$, and $19.9 \% \mathrm{ADF}$ ) until $210 \pm 13 \mathrm{DIM}$, and then the same late-lactation ration (1.6 Mcal of $\mathrm{NE}_{\mathrm{L}} / \mathrm{kg}$ of $\mathrm{DM}, 16.5 \% \mathrm{CP}, 36.2 \%$ $\mathrm{NDF}$, and $23.2 \% \mathrm{ADF}$ ) was fed until the end of the experiment.

\section{Data Collection}

Individual MY was recorded manually every other day during the first 60 DIM and on 2 consecutive days per week afterward. Feed was introduced to all treatment groups 3 times daily and orts were measured daily. Average individual feed intake was calculated by subtracting orts from introduced feed and dividing by the number of cows present. Dry matter content and chemical composition of the feed and ort samples was determined monthly. Cows were weighed and scored for their body condition after morning milking and before the morning meal on 2,30,60,90,120,150,210, and 270 DIM. Body condition scores were assigned using a 5 -point scale $(1=$ thin to $5=$ obese; Wildman et al., 1982). Blood samples were collected from tail vein on the same days and hour of the day as weighing and body condition scoring, with an additional blood sampling on 15 DIM. Plasma samples were immediately harvested by centrifuging at $3,000 \times \mathrm{g}$ for $15 \mathrm{~min}$ and were stored at $-20^{\circ} \mathrm{C}$ until analysis. Milk samples were taken monthly at all milking times on the days following weighing and body condition scoring.

\section{Chemical Analysis}

Plasma samples were analyzed for glucose, triglyceride, total protein, phosphorus, NEFA and BHBA, aspartate aminotransferase, and BUN concentration using enzymatic method and appropriate kits (NEFA and BHBA: Randox Laboratories Ltd., Crumlin, UK; other metabolites: Pars-azmon Co., Tehran, Iran) and Clima Plus Analyzer (RAL, Madrid, Spain). Plasma prolactin (PRL) concentration was determined using a double antibody RIA procedure (Ayad et al., 2007). Milk samples were used for fat, protein, lactose, SNF, TS, and MUN analysis by infrared spectrophotometry (Foss Electric, Hillerød, Denmark) and for SCC by automatic counter (Fossmatic 5000 Automatic Counter, Foss Electric).

\section{Statistical Analysis}

Milk yield, DMI, milk composition, SCC, milk constituent yield, plasma metabolites, BW change, and BCS data were analyzed using the MIXED procedure of SAS (SAS Institute, 2003), treating cow as a random effect. Daily milk yields were collapsed into monthly averages. Energy-corrected milk was calculated from milk, protein, and fat volumes $[0.327 \times$ milk $(\mathrm{kg})+$ $12.95 \times$ milk fat $(\mathrm{kg})+7.2 \times$ milk protein $(\mathrm{kg})]$, and $3.5 \%$ FCM was calculated from milk fat yield [0.4148 $\times$ milk $(\mathrm{kg})+16.7 \times$ milk fat $(\mathrm{kg})]$. Model equation included treatment, time, treatment $\times$ time interaction, and parity. Significance level was set at $P<0.05$ and individual comparison of treatments was made by Tukey's standardized multiple comparison tests.

\section{RESULTS}

\section{Milk Production and Composition}

Average milk (LSM) production responses are shown in Table 1. Average daily milk yield was higher in $6 \times$ and $6 \times-3 \times$ cows than in $3 \times$ cows (Table 1 ). Average daily milk yields were $36.82,36.1$, and $34.56 \mathrm{~kg} / \mathrm{d}$ for $6 \times, 6 \times-3 \times$, and $3 \times$ cows, respectively. Peak MY occurred during mo 2 for $6 \times-3 \times$ cows and during mo 3 for $6 \times$ and $3 \times$ cows (Figure 1 ). Average daily milk production decreased dramatically $(-2.35 \mathrm{~kg})$ while still milking 6 times daily in the $6 \times-3 \times$ group during mo 3 , whereas there was no considerable change in the $6 \times$ and $3 \times$ groups during this period $(+0.58$ and +0.64 $\mathrm{kg}$, respectively). The interaction between parity and milking frequency treatment was not significant.

Milk component concentrations are shown in Table 1. Milk fat and lactose concentration was not statistically different among treatment groups, but $6 \times$ cows had lower protein and SNF percentages than $6 \times-3 \times$ and $3 \times$ cows. The $3 \times$ cows had the highest TS percentage.

The $3.5 \%$ FCM and milk components yield are shown in Table 1. Fat yield tended to be higher in $6 \times$ and $6 \times-3 \times$ cows compared with $3 \times$ cows $(P=0.06)$, but it was not significantly different between $6 \times$ and $6 \times$ $3 \times$ groups. The $6 \times$ and $6 \times-3 \times$ cows produced 60,50 , 
4056

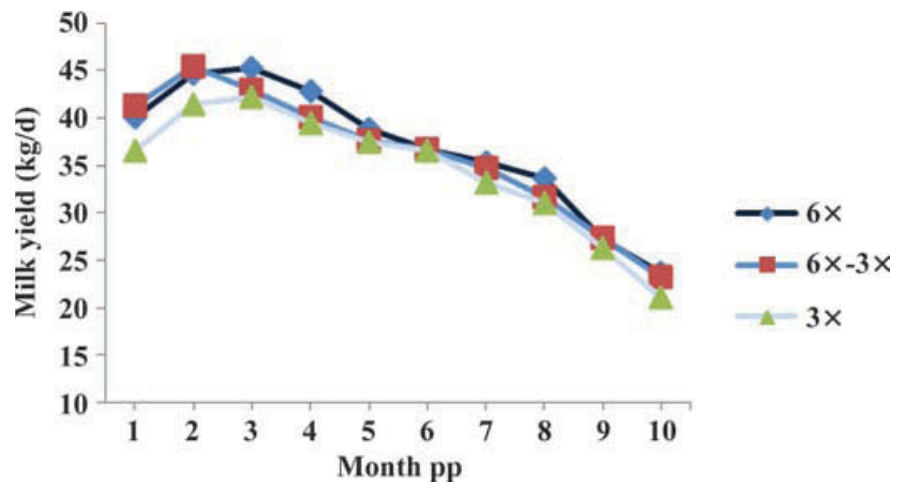

Figure 1. Effects of milking frequency on milk production of cows. $6 \times=$ milking 6 times daily for the entire lactation; $6 \times-3 \times=$ milking 6 times daily for the first 90 DIM and switching to 3 times daily subsequently; $3 \times=$ milking 3 times daily for the entire lactation; pp $=$ postpartum. Color version available in online PDF.

and 120 and 40, 50, and $100 \mathrm{~g}$ more fat, protein, and lactose per day, respectively, compared with $3 \times$ cows. The $6 \times-3 \times$ and $3 \times$ groups had the highest SNF and TS yields, respectively. Fat-corrected milk showed the same pattern as milk production across groups. During the period of 0 to 3 mo postpartum (pp), $6 \times$ and $6 \times-$ $3 \times$ cows produced more FCM and ECM than did $3 \times$ cows, but FCM and ECM were not statistically different among groups during mo 4 to 10. Regarding full experimental period, the average daily FCM and ECM were higher in $6 \times$ and $6 \times-3 \times$ cows than in $3 \times$ cows $(\mathrm{FCM}$ : $37.32,36.75$, and $35.33 \mathrm{~kg} / \mathrm{d}$; ECM: $37.17,36.75$, and $35.17 \mathrm{~kg} / \mathrm{d}$ ) and was not statistically different between $6 \times$ and $6 \times-3 \times$ cows. Average milk SCC did not differ across treatment groups during mo 4 to $10(P>0.05)$, but it was lower for $6 \times$ and $6 \times-3 \times$ cows in the first 3 mo of the experiment $(P<0.01)$. The $6 \times$ cows had the lowest average SCC in the full experimental period (Table 1).

\section{$B W, B C S$, and DMI}

The BW change and BCS of cows are shown in Figure 2 and Table 2 . The $3 \times$ cows started to gain weight earlier than the $6 \times$ and $6 \times-3 \times$ cows $(\mathrm{d} 45,60$, and 67 pp, respectively). During d 90 to $270,6 \times$ and $6 \times-3 \times$ cows compensated for the more severe BW loss experienced during the first 3 mo of lactation, resulting in no significant difference in average BW change among treatment groups during entire experimental period $(P$ $=0.91$ ). The average monthly BW change was 11.42 , 10.72 , and $10.74 \mathrm{~kg}$ in $6 \times, 6 \times-3 \times$, and $3 \times$ cows, respectively. Body condition score showed the same pattern as BW among treatments and all cows had almost equal BCS at the end of the trial (Figure 2).

Average DMI was not different among treatment groups in the first 3 mo pp but during mo 4 to $10 \mathrm{pp}$

Table 1. Least squares means for milk yields, milk composition, and SCC in different milking frequency treatments

\begin{tabular}{lcccccc}
\hline & & \multicolumn{3}{c}{ Treatment $^{1}$} & & \\
\cline { 3 - 4 } Item & $\begin{array}{c}\text { Month } \\
\text { postpartum }\end{array}$ & $6 \times$ & $6 \times-3 \times$ & $3 \times$ & SEM & $P$-value \\
\cline { 3 - 5 } Milk (kg/d) & $0-3$ & $41.16^{\mathrm{a}}$ & $41.01^{\mathrm{a}}$ & $37.66^{\mathrm{b}}$ & 0.73 & $<0.001$ \\
& $4-10$ & $34.85^{\mathrm{a}}$ & $33.89^{\mathrm{ab}}$ & $33.14^{\mathrm{b}}$ & 0.71 & $<0.05$ \\
& $0-10$ & $36.82^{\mathrm{a}}$ & $36.1^{\mathrm{a}}$ & $34.56^{\mathrm{b}}$ & 0.53 & $<0.001$ \\
$3.5 \%$ FCM (kg/d) & $0-3$ & $40.53^{\mathrm{a}}$ & $41.16^{\mathrm{a}}$ & $34.98^{\mathrm{b}}$ & 0.99 & $<0.001$ \\
& $4-10$ & 35.38 & 34.51 & 34.08 & 0.80 & NS \\
& $0-10$ & $37.32^{2}$ & $36.75^{\mathrm{a}}$ & $35.33^{\mathrm{b}}$ & 0.68 & $<0.01$ \\
ECM (kg/d) & $0-3$ & $39.82^{\mathrm{a}}$ & $40.45^{\mathrm{a}}$ & $36.85^{\mathrm{b}}$ & 1.03 & $<0.001$ \\
& $4-10$ & 35.51 & 34.81 & 34.15 & 0.77 & NS \\
Fat (\%) & $0-10$ & $37.17^{\mathrm{a}}$ & $36.75^{\mathrm{a}}$ & $35.17^{\mathrm{b}}$ & 0.64 & $<0.001$ \\
Fat yield (kg/d) & $0-10$ & 3.57 & 3.50 & 3.62 & 0.05 & NS \\
Protein (\%) & $0-10$ & 1.31 & 1.29 & 1.25 & 0.03 & NS \\
Protein yield (kg/d) & $0-10$ & $3.00^{\mathrm{b}}$ & $3.05^{\mathrm{a}}$ & $3.06^{\mathrm{a}}$ & 0.01 & $<0.001$ \\
Lactose (\%) & $0-10$ & $1.11^{\mathrm{a}}$ & $1.11^{\mathrm{a}}$ & $1.06^{\mathrm{b}}$ & 0.02 & $<0.01$ \\
Lactose yield (kg/d) & $0-10$ & 4.57 & 4.59 & 4.56 & 0.03 & NS \\
SNF (\%) & $0-10$ & $1.70^{\mathrm{a}}$ & $1.68^{\mathrm{a}}$ & $1.58^{\mathrm{b}}$ & 0.03 & $<0.01$ \\
TS (\%) & $0-10$ & $8.47^{\mathrm{b}}$ & $8.57^{\mathrm{a}}$ & $8.52^{\mathrm{ab}}$ & 0.03 & $<0.05$ \\
MUN (mg/dL) & $0-10$ & $11.95^{\mathrm{b}}$ & $12.07^{\mathrm{ab}}$ & $12.18^{\mathrm{a}}$ & 0.07 & $<0.01$ \\
SCC (1,000 cells/mL) & $0-10$ & $21.89^{\mathrm{c}}$ & $22.49^{\mathrm{b}}$ & $23.06^{\mathrm{a}}$ & 0.39 & $<0.05$ \\
& $0-3$ & $82.25^{\mathrm{b}}$ & $46.38^{\mathrm{b}}$ & $184.95^{\mathrm{a}}$ & 22.96 & $<0.01$ \\
& $4-10$ & 184.5 & 237.29 & 218.58 & 38.41 & NS \\
& $0-10$ & 154 & 179.28 & 228.41 & 23.83 & NS \\
\hline
\end{tabular}

${ }^{\mathrm{a}-\mathrm{c}}$ Means within a row with different superscripts differ $(P<0.05)$.

${ }^{1}$ Treatments: $6 \times=$ milking 6 times daily for the entire lactation; $6 \times-3 \times=$ milking 6 times daily for the first 90 DIM and switching to milking 3 times daily afterward; $3 \times=$ milking 3 times daily for the entire lactation.

${ }^{2} \mathrm{NS}: P>0.05$. 

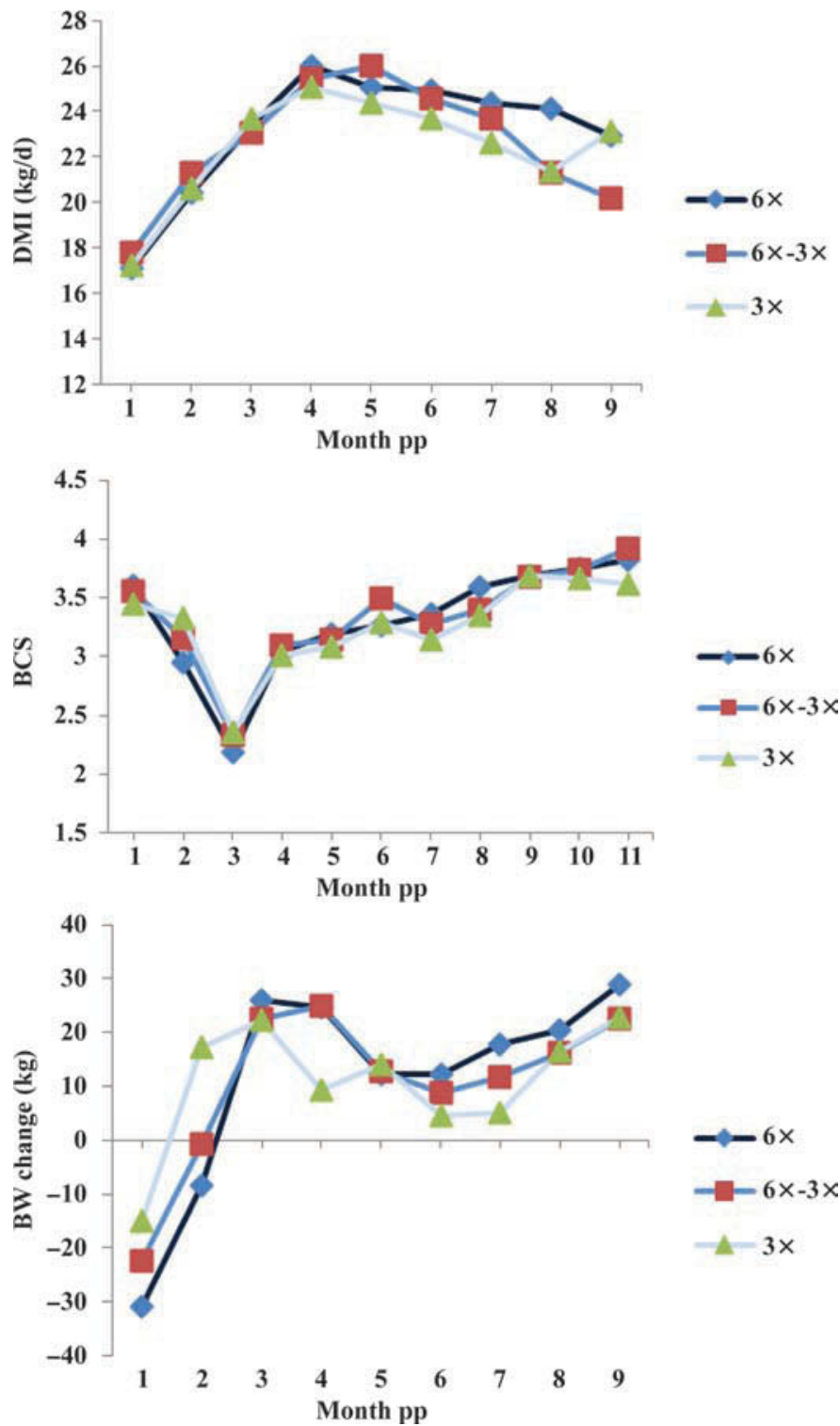

Figure 2. Effects of milking frequency on DMI, BCS, and BW change of cows. $6 \times=$ milking 6 times daily for the entire lactation; $6 \times-3 \times=$ milking 6 times daily for the first 90 DIM and switching to 3 times daily subsequently; $3 \times=$ milking 3 times daily for the entire lactation; $\mathrm{pp}=$ postpartum. Color version available in online PDF.

DMI decreased at higher rates in $6 \times-3 \times$ and $3 \times$ cows than in $6 \times$ cows (Figure 2), resulting in higher average DMI in $6 \times$ cows compared with $6 \times-3 \times$ and $3 \times$ cows during entire experimental period $(23.05,22.58$, and $22.45 \mathrm{~kg} / \mathrm{d}$, respectively).

\section{Blood Metabolites}

Plasma concentration of glucose was higher $(P<$ $0.05)$ in $3 \times$ cows only during the first 2 mo pp compared with $6 \times$ and $6 \times-3 \times$ cows (Figure 3 ). The average plasma NEFA concentration was not different across treatments during the first 3 mo pp but it was higher during the remainder of the experimental period in $6 \times$ and $6 \times-3 \times$ cows $(P<0.01)$, resulting in higher average NEFA concentration in $6 \times$ and $6 \times-3 \times$ cows than in $3 \times$ cows during the full experimental period $(P<0.01)$. The $3 \times$ cows had the lowest average BHBA concentration $(P<0.05)$ during both the first 3 mo pp and the full experimental period $(P<0.01)$. Plasma urea, total protein, phosphorus, and triglyceride concentrations were not affected by milking frequency treatment. Plasma aspartate aminotransferase tended to be higher $(P=0.07)$ in $6 \times$ cows compared with $6 \times-3 \times$ and $3 \times$ cows (Table 3 ). Frequent milking did not alter the concentrations of plasma PRL at any specific sampling time during the experimental period. Plasma PRL concentration was $57.73,59.62$, and $58.87 \mathrm{ng} / \mathrm{mL}$ for $6 \times$, $6 \times-3 \times$, and $3 \times$ cows, respectively.

\section{DISCUSSION}

Increasing milking frequency from 3 times daily to 6 times daily at the first 3 mo of lactation increased average milk production by $3.35 \mathrm{~kg} / \mathrm{d}(8.89 \%)$ in the $6 \times-3 \times$ group at that period. Similar differences were observed in other studies where 6 times daily milking was compared with 3 times daily milking (Bar-Peled et al., 1995; Sanders., 2000) and studies where 4 times daily milking was compared with twice daily milking (Hale et al., 2003). Bar-Peled et al. (1995) reported an increase of $7.3 \mathrm{~kg} / \mathrm{d}(21 \%)$ in MY for cows milked 6 times daily compared with cows milked 3 times daily during a 6 -wk treatment period. Also, Hale et al. (2003) reported an increase of $8.8 \mathrm{~kg} / \mathrm{d}(26 \%)$ in MY for cows milked 4 times daily compared with cows milked 3 times daily during a 3 -wk treatment period, and Sanders (2000) saw a $6 \mathrm{~kg} / \mathrm{d}(16 \%)$ increase in MY in cows milked 6 times daily compared with mature cows milked 3 times daily. Previous work by Wilde et al. (1995) proposed the hypothesis that increased MY as a result of IMF was attributable to the removal of a whey protein, referred to as the feedback inhibitor of lactation (FIL), from the mammary gland. High concentrations of FIL in the mammary gland have been associated with decreased milk secretion by mammary epithelial cells (Wilde et al., 1995), and more frequent removal of milk may rid the mammary gland of FIL, therefore maintaining higher rates of milk secretion (Henderson and Peaker, 1984). To our knowledge, ours is the first IMF study that increased milking frequency to 6 times daily for the entire lactation period. Increasing milking frequency from 3 to 6 times daily during entire lactation period increased milk production only during the first 4 mo of lactation $(9.13 \%)$ in the $6 \times$ group compared with 
Table 2. Least squares means of DMI, BCS, and BW change of cows in different milking frequency treatments

\begin{tabular}{lccccccc}
\hline & & \multicolumn{3}{c}{ Treatment $^{1}$} & & \\
\cline { 3 - 5 } Item & $\begin{array}{c}\text { Month } \\
\text { postpartum }\end{array}$ & $6 \times$ & $6 \times-3 \times$ & $3 \times$ & & SEM & $P$-value \\
\hline DMI $(\mathrm{kg} / \mathrm{d})$ & $0-3$ & 20.31 & 20.71 & 20.49 & 0.28 & $\mathrm{NS}^{2}$ \\
& $4-10$ & $24.22^{\mathrm{a}}$ & $23.38^{\mathrm{b}}$ & $23.29^{\mathrm{b}}$ & 0.12 & $<0.01$ \\
BW change $(\mathrm{kg} / \mathrm{mo})$ & $0-10$ & $23.05^{\mathrm{a}}$ & $22.58^{\mathrm{b}}$ & $22.45^{\mathrm{b}}$ & 0.12 & $<0.01$ \\
& $0-3$ & $-2.80^{\mathrm{b}}$ & $1.76^{\mathrm{b}}$ & $9.95^{\mathrm{a}}$ & 3.45 & $<0.01$ \\
& $4-10$ & $18.99^{\mathrm{a}}$ & $15.56^{\mathrm{ab}}$ & $11.36^{\mathrm{b}}$ & 1.75 & $<0.01$ \\
BCS & $0-10$ & 11.42 & 10.72 & 10.74 & 1.88 & NS \\
& $0-3$ & $2.81^{\mathrm{b}}$ & $2.94^{\mathrm{a}}$ & $2.98^{\mathrm{a}}$ & 0.047 & $<0.01$ \\
& $4-10$ & $3.44^{\mathrm{a}}$ & $3.44^{\mathrm{a}}$ & $3.32^{\mathrm{b}}$ & 0.051 & $<0.05$ \\
& $0-10$ & 3.29 & 3.32 & 3.25 & 0.037 & $\mathrm{NS}$ \\
\hline
\end{tabular}

${ }^{\mathrm{a}, \mathrm{b}}$ Means within a row with different superscripts differ $(P<0.05)$.

${ }^{1}$ Treatments: $6 \times=$ milking 6 times daily for the entire lactation; $6 \times-3 \times=$ milking 6 times daily for the first 90 DIM and switching to milking 3 times daily afterward; $3 \times=$ milking 3 times daily for the entire lactation.

${ }^{2} \mathrm{NS}: P>0.05$.

the $3 \times$ group and did not show any advantages over the $6 \times-3 \times$ group. It is possible that during mid and late lactation mammary gland capacity may be a limiting factor for response to frequent milking. However, Amos et al. (1985) increased milking frequency from 2 to 3 times daily and reported increased milk production both at peak and throughout the entire lactation. Persistency of lactation was also slightly increased but this effect disappeared after approximately 180 DIM. Lactation persistency in the present study was not as long as it was in Amos et al. (1985). Amos et al. (1985) increased milking frequency from 2 to 3 times daily compared with this study, which increased frequency from 3 to 6 times daily. It is possible that frequency of milking relative to mammary gland capacity is the main factor determining the magnitude and duration of MY response. Using a half udder model, Stelwagen and Knight (1997) compared once daily milking with twice daily milking of cows in early and late lactation and reported a more dramatic increase in milk secretion efficiency in response to twice daily milking during early lactation compared with late lactation. It is possible that during early lactation more secretory cells are present in the mammary gland and those cells may have more potential to respond to stimulus than cells present in late lactation (Wall and McFadden, 2008), and milking 6 times daily during late lactation may exceed mammary gland capacity to secrete more milk.

Cows from the $6 \times-3 \times$ treatment did not show carryover effect of 6 times daily milking on milk production and decreased milk production even before switching from 6 times daily to 3 times daily milking. Those cows are likely to experience lactation curve collapse that may happen in cases of strong negative energy balance (NEB) and is also reflected by a sharp decline in BW (Figure 2). Analysis of milk, FCM, and ECM yield data for the first 2 mo of lactation indicated that $6 \times-3 \times$ cows produced an average of $0.89,1.43$, and 1.34 $\mathrm{kg} / \mathrm{d}$ more milk, FCM, and ECM, respectively than $6 \times$ cows during this period. On the other hand, the mean lactation number and initial BW for $6 \times, 6 \times-3 \times$, and $3 \times$ cows were 3.63 and 668.16, 2.98 and 632.30, and 3.15 and 636.15 , respectively. This means that $6 \times-3 \times$ cows were less mature than cows from other groups and lacked enough body reserves to support lactation. The $6 \times$ cows lost more BW than the $6 \times-3 \times$ cows and did not experience the lactation curve collapse (Figure 2), but they were mature enough to avoid lactation curve collapse because more mature cows release more energy per unit of BCS loss (NRC, 2001).

It has long been thought that hormones released at milking may be involved in regulating the galactopoietic effects of frequent milking on milk production (Wall and McFadden, 2008). Bar-Peled et al. (1995) observed increased concentrations of PRL in circulation of cows that were frequently milked or milked and suckled. Consequently, PRL has been hypothesized as a candidate regulator of the effects of frequent milking on milk production (Dahl et al., 2004). In an attempt to determine whether milking-induced PRL release mediates the effects of frequent milking on milk production, cows have been assigned to twice daily milking, 4 times daily milking, or twice daily milking plus twice daily injections of PRL (Wall et al., 2006). Consistent with our results, the results of such studies supported the concept that frequent milking stimulates milk production via local factors rather than stimulating PRL secretion. Although PRL is essential for successful lactation in rodents, no evidence exists of any galactopoietic effects during established lactation in ruminants (Bar-peled et al., 1995). Sorensen et al (1998) recently compared PRL in cows of high and low genetic merit and found 
no difference despite a $33 \%$ difference in MY. Knight (2001) suggested that those species that man has selectively bred to produce milk for his benefit appear to have largely escaped from reliance on PRL to support lactation and growth hormone overtook some of the responsibility for maintaining MY. This has further been evidenced by several studies that failed to increase MY by administration of exogenous PRL (Cotes et al., 1949; Plaut et al., 1987).

No interaction between parity and response to frequent milking was observed in the present study. Results of reported studies in this regard have been inconsistent. Some studies have reported more pronounced response to frequent milking in animals with smaller udder capacity such as heifers (Allen et al., 1986), whereas others reported that mature cows respond to frequent milking similar to or better than primiparous cows (DePeters et al., 1985). Therefore, no relationship has been established between parity and the magnitude of the MY response to frequent milking (Wall and McFadden, 2008).

Increased milking frequency treatment generally alters milk composition, specifically, fat and protein contents. Usually, as milking frequency increases, milk fat and protein concentration decrease (Erdman and Varner, 1995). In the present study, increasing milking frequency to 6 times daily for the entire lactation did not alter milk fat and lactose percentages during either treatment or during the posttreatment period. Milk protein was lower for $6 \times$ cows compared with $6 \times-3 \times$ and $3 \times$ cows; this difference appeared during mo 6 to 10 and resulted in lower SNF percentage in milk of this group. Consistent with the results of this study, Hale et al. (2003) reported that cows milked 4 times daily tended to have lower milk protein percentages during the posttreatment period (wk 4 to 44 ). Fat yield tended to be higher in $6 \times$ and $6 \times-3 \times$ cows than that in $3 \times$ cows, and protein and lactose yield was significantly higher in $6 \times$ and $6 \times-3 \times$ cows than in $3 \times$ cows. These differences were likely attributable to increased MY in $6 \times$ and $6 \times-3 \times$ cows. Yield of FCM showed the same pattern as MY; milk fat percentage was not affected by treatment. Many researchers have observed no effect of frequent milking on milk composition (Amos et al., 1985; DePeters et al., 1985; Gisi et al., 1986), whereas some have observed a decrease in fat percentage (Allen et al., 1986; Smith et al., 2002).

Milking frequency affected milk SCC (Table 1). In other studies a shift from twice daily to 3 times daily milking decreased bulk milk SCC and the proportion of high SCC cows (Hogeveen et al., 2001). Waterman et al. (1983) reported no difference in SCC between cows milked 3 times or twice daily, although they reported a decreasing trend for SCC in cows milked 3 times daily.
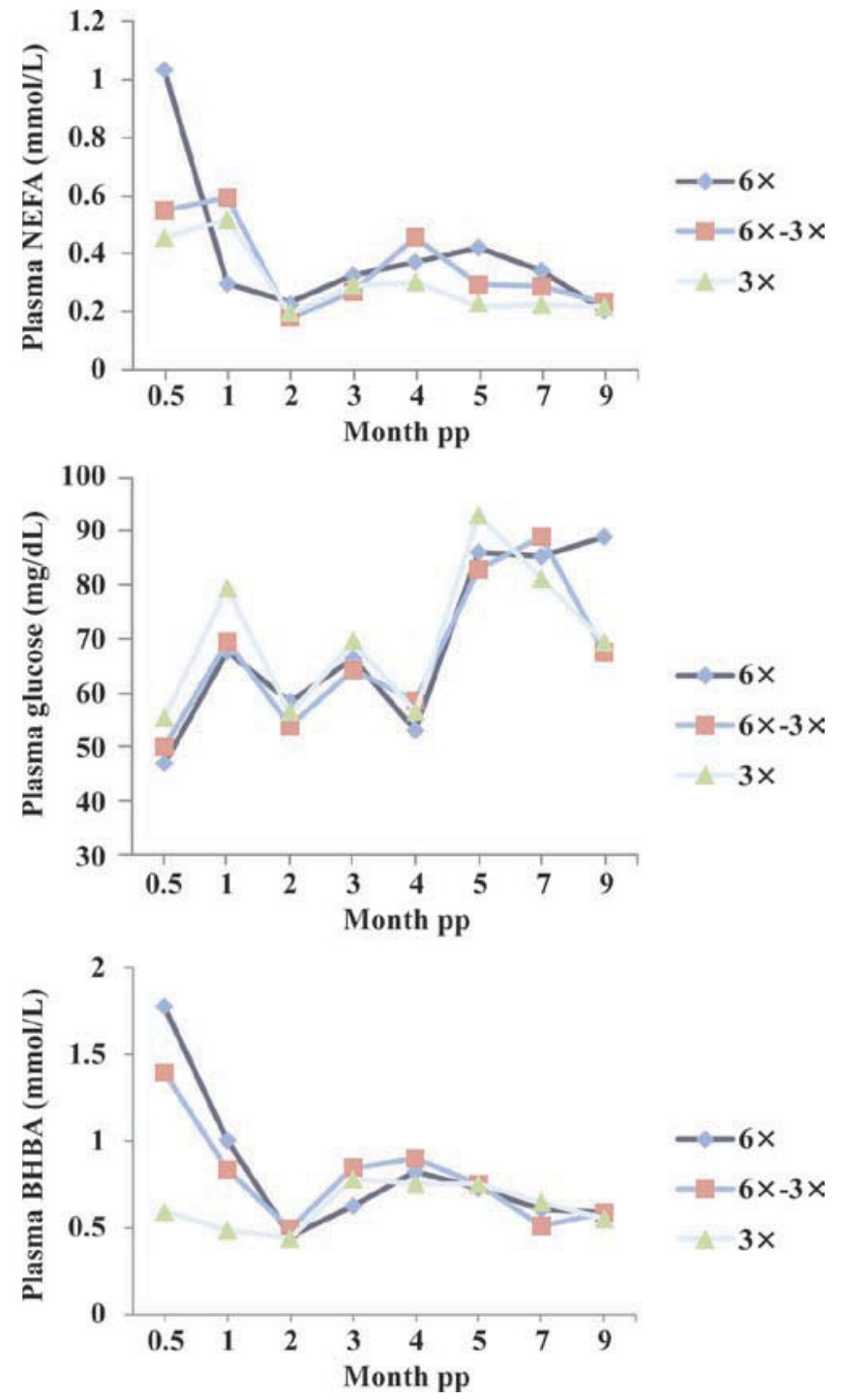

Figure 3. Effects of milking frequency on plasma concentrations of glucose, NEFA, and BHBA. $6 \times=$ milking 6 times daily for the entire lactation; $6 \times-3 \times=$ milking 6 times daily for the first 90 DIM and switching to 3 times daily subsequently; $3 \times=$ milking 3 times daily for the entire lactation; $p p=$ postpartum. Color version available in online PDF.

Reported effects of frequent milking on milk composition, SCC, and herd health have been inconsistent. Inconsistencies in the reports may be the result of variations in timing and methods of sampling across experiments (Wall and McFadden, 2008).

Increased milk production has an energy cost. Thus, cows in the $6 \times$ group consumed more DM than cows in the $3 \times$ group. However, this difference was not observed during the full experimental period. During mo 0 to 4 , average DMI was similar among different groups, but $6 \times-3 \times$ and $3 \times$ cows reduced their DMI at higher rates than $\operatorname{did} 6 \times$ cows during remainder of the experimental 
Table 3. Least squares means for plasma metabolites of cows in different milking frequency treatments

\begin{tabular}{|c|c|c|c|c|c|c|}
\hline \multirow[b]{2}{*}{ Item } & \multirow{2}{*}{$\begin{array}{c}\text { Month } \\
\text { postpartum }\end{array}$} & \multicolumn{3}{|c|}{ Treatment $^{1}$} & \multirow[b]{2}{*}{ SEM } & \multirow[b]{2}{*}{$P$-value } \\
\hline & & $6 \times$ & $6 \times-3 \times$ & $3 \times$ & & \\
\hline \multirow[t]{3}{*}{ Glucose $(\mathrm{mg} / \mathrm{dL})$} & $0-3$ & $58.00^{\mathrm{b}}$ & $58.68^{\mathrm{b}}$ & $64.85^{\mathrm{a}}$ & 2.47 & $<0.05$ \\
\hline & $4-10$ & 75.71 & 71.85 & 73.88 & 1.89 & NS \\
\hline & $0-10$ & 69.06 & 66.95 & 70.55 & 1.5 & NS \\
\hline \multirow[t]{3}{*}{ NEFA (mmol/L) } & $0-3$ & 0.49 & 0.41 & 0.36 & 0.06 & NS \\
\hline & $4-10$ & $0.35^{\mathrm{a}}$ & $0.33^{\mathrm{a}}$ & $0.28^{\mathrm{b}}$ & 0.03 & $<0.01$ \\
\hline & $0-10$ & $0.41^{\mathrm{a}}$ & $0.36^{\mathrm{ab}}$ & $0.31^{\mathrm{b}}$ & 0.04 & $<0.01$ \\
\hline \multirow[t]{3}{*}{$\mathrm{BHBA}(\mathrm{mmol} / \mathrm{L})$} & $0-3$ & $1.38^{\mathrm{a}}$ & $1.21^{\mathrm{a}}$ & $0.90^{\mathrm{b}}$ & 0.23 & $<0.05$ \\
\hline & $4-10$ & 0.59 & 0.64 & 0.60 & 0.06 & NS \\
\hline & $0-10$ & $0.83^{\mathrm{a}}$ & $0.79^{\mathrm{a}}$ & $0.63^{\mathrm{b}}$ & 0.06 & $<0.01$ \\
\hline \multirow[t]{3}{*}{ Triglycerides $(\mathrm{mg} / \mathrm{dL})$} & $0-3$ & 9.41 & 10.43 & 11.12 & 1.21 & NS \\
\hline & $4-10$ & 10.75 & 9.94 & 12.03 & 1.91 & NS \\
\hline & $0-10$ & 10.78 & 10.67 & 12.41 & 1.45 & NS \\
\hline \multirow[t]{3}{*}{ Total protein $(\mathrm{g} / \mathrm{dL})$} & $0-3$ & 7.75 & 8.06 & 7.65 & 0.23 & NS \\
\hline & $4-10$ & 9.74 & 9.82 & 9.98 & 0.3 & NS \\
\hline & $0-10$ & 8.95 & 9.12 & 9.05 & 0.23 & NS \\
\hline \multirow[t]{3}{*}{ Phosphorus (mg/dL) } & $0-3$ & 6.21 & 5.73 & 5.65 & 0.41 & NS \\
\hline & $4-10$ & 7.02 & 7.07 & 7.25 & 0.22 & NS \\
\hline & $0-10$ & 6.87 & 6.71 & 6.84 & 0.16 & NS \\
\hline \multirow[t]{3}{*}{ BUN (mg/dL) } & $0-3$ & 21.26 & 23.12 & 21.44 & 1.83 & NS \\
\hline & $4-10$ & 20.89 & 19.57 & 19.46 & 0.62 & NS \\
\hline & $0-10$ & 21.89 & 21.44 & 21.25 & 0.95 & NS \\
\hline \multirow[t]{3}{*}{ Aspartate aminotransferase $(\mathrm{U} / \mathrm{L})$} & $0-3$ & 77.33 & 70.91 & 70.51 & 5.53 & NS \\
\hline & $4-10$ & 59.19 & 52.45 & 51.76 & 5.49 & NS \\
\hline & $0-10$ & 69.80 & 63.01 & 63.35 & 2.07 & NS \\
\hline \multirow{3}{*}{ Plasma prolactin $(\mathrm{ng} / \mathrm{mL})$} & $0-3$ & 60.35 & 64.82 & 62.35 & 2.70 & NS \\
\hline & $4-10$ & 55.30 & 55.26 & 55.75 & 2.08 & NS \\
\hline & $0-10$ & 57.73 & 59.62 & 58.87 & 1.56 & NS \\
\hline
\end{tabular}

${ }^{\mathrm{a}, \mathrm{b}}$ Means within a row with different superscripts differ $(P<0.05)$.

${ }^{1}$ Treatments: $6 \times=$ milking 6 times daily for the entire lactation; $6 \times-3 \times=$ milking 6 times daily for the first 90 DIM and switching to milking 3 times daily afterward; $3 \times=$ milking 3 times daily for the entire lactation.

${ }^{2} \mathrm{NS}: P>0.05$.

period (Figure 2). These results are in agreement with results of VanBaale et al. (2005), who reported no significant difference in DMI between cows milked 6 and 3 times daily during the treatment period. In contrast, Bar-Peled et al. (1995) reported an increase in DMI for cows milked 6 times daily compared with those milked 3 times daily (19.4 vs. $16.8 \mathrm{~kg} / \mathrm{d}$ from 0 to 42 DIM and 22.4 vs. $20.1 \mathrm{~kg} / \mathrm{d}$ from 49 to $70 \mathrm{DIM})$. The reason why $6 \times$ cows consumed more DM than $6 \times-3 \times$ and $3 \times$ cows during mo 4 to 10 may be that these cows spent more time daily walking to the milking parlor and therefore spent more time standing by the feeding bunk and eating. Increased energy demand because of IMF does not always increase DMI. Bar-Peled et al. (1998) reported that cows milked and suckled by calves 6 times daily had higher MY than cows milked 6 times whereas their DMI was the lowest in their experiment. Also, in the present study, $6 \times-3 \times$ cows had lower DMI compared with $6 \times$ cows despite increased milk production.

The $3 \times$ cows started to gain weight earlier than cows in other treatments. Increased energy demand because of increased MY in the $6 \times$ and $6 \times-3 \times$ groups and their almost identical DMI to the $3 \times$ group led to more $\mathrm{BW}$ loss and lower BCS in these cows during the early lacta- tion period; these cows also displayed a longer recovery period than did cows in the $3 \times$ group. There was no significant effect of IMF treatment on body condition during the full experimental period.

Consistent with the reported literature (Patton et al., 2006; McNamara et al., 2008; Loiselle et al., 2009), plasma glucose concentration decreased and plasma NEFA and BHBA concentration increased $(P<0.05)$ by more frequent milking. Higher MY probably drained plasma glucose into mammary gland for lactose production whereas DMI was not increased to the same extent as MY to replace drained glucose during the first 3 mo pp, resulting in more severe NEB in $6 \times$ and $6 \times-3 \times$ cows compared with $3 \times$ cows, evidenced by the increase in plasma NEFA and BHBA concentration and BW change pattern of cows milked more frequently. During mo 4 to 10, MY decreased whereas plasma glucose concentration was not different among treatments.

\section{CONCLUSIONS}

Milking 6 times daily for the entire lactation has no advantage over milking 6 times daily for $90 \mathrm{~d}$ in early lactation and subsequently switching to milk- 
ing 3 times daily. Furthermore, $6 \times-3 \times$ cows produced $469.7 \mathrm{~kg}$ more milk and $433.1 \mathrm{~kg}$ more FCM during the entire experimental period than did $3 \times$ cows. Increasing milking frequency, although it increased MY, did not alter DMI in early lactation and resulted in more BW loss and more severe NEB. The severity of NEB was further evidenced by decreased plasma concentrations of glucose and increased plasma concentrations of plasma NEFA and BHBA. These results indicate that increasing milking frequency to 6 times daily for the first 90 DIM may be an effective strategy to increase the profitability of dairy industry, although further investigations are needed to determine the consequences of this milking frequency treatment on the health and reproductive performance of cows.

\section{ACKNOWLEDGMENTS}

The authors thank Ministry of Science, Research and Technology of Iran (Tehran) for financial support and Bijin Dairy Institute (Tehran, Iran) manager and staff for cooperation and financial support.

\section{REFERENCES}

Allen, D. B., E. J. DePeters, and R. C. Laben. 1986. Three times a day milking: Effects on milk production, reproductive efficiency, and udder health. J. Dairy Sci. 69:1441-1446.

Amos, H. E., T. Kiser, and M. Loewenstein. 1985. Influence of milking frequency on productive and reproductive efficiencies of dairy cows. J. Dairy Sci. 68:732-739.

Ayad, A., N. M. Sousa, J. Sulon, J. L. Hornick, J. Watts, F. LópezGatius, M. Iguer-Ouada, and J. F. Beckers. 2007. Influence of progesterone concentrations on secretory functions of trophoblast and pituitary during the first trimester of pregnancy in dairy cattle. Theriogenology 67:1503-1511.

Bar-Peled, U., Y. Aharoni, B. Robinzon, I. Bruckental, R. Lehrer, E. Maltz, C. Knight, J. Kali, Y. Folman, H. Voet, H. Gacitua, and H. Tagari. 1998. The effect of enhanced milk yield of dairy cows by frequent milking or suckling on intake and digestibility of the diet. J. Dairy Sci. 81:1420-1427.

Bar-Peled, U., E. Maltz, I. Bruckental, Y. Folman, Y. Kali, H. Gacitua, A. R. Lehrer, C. H. Knight, B. Robinson, and H. Voet. 1995. Relationship between frequent milking or suckling in early lactation and milk production of high producing dairy cows. J. Dairy Sci. 78:2726-2736.

Blevins, C. A., J. E. Shirley, and J. S. Stevenson. 2006. Milking frequency, estradiol cypionate, and somatotropin influence lactation and reproduction in dairy cows. J. Dairy Sci. 89:4176-4187.

Cotes, P. M., J. A. Crichton, S. J. Folley, and F. G. Young. 1949. Galactopoietic activity of purified anterior pituitary growth hormone. Nature 164:992-993.

Dahl, G. E., R. L. Wallace, R. D. Shanks, and D. Lueking. 2004. Hot topic: Effects of frequent milking in early lactation on milk yield and udder health. J. Dairy Sci. 87:882-885.

DePeters, E. J., N. E. Smith, and J. Acedo-Rico. 1985. Three or two times daily milking of older cows and first lactation cows for entire lactations. J. Dairy Sci. 68:123-132.

Erdman, R. A., and M. Varner. 1995. Fixed yield responses to increased milking frequency. J. Dairy Sci. 78:1199-1203.

Gisi, D. D., E. J. DePeters, and C. L. Pelissier. 1986. Three times daily milking of cows in California dairy herds. J. Dairy Sci. 69:863-868.
Hale, S. A., A. V. Capuco, and R. A. Erdman. 2003. Milk yield and mammary growth effects due to increased milking frequency during early lactation. J. Dairy Sci. 86:2061-2071.

Henderson, A. J., and M. Peaker. 1984. Feed-back control of milk secretion in the goat by a chemical in milk. J. Physiol. 351:3945.

Hogeveen, H., J. D. Miltenburg, S. den Hollander, and K. Drandena. 2001. Milking three times a day and its effect on udder health and production. Intl. Dairy Fed. Mastitis Newsletter 24:7.

Knight, C. H. 2001. Overview of prolactin's role in farm animal lactation. Livest. Prod. Sci. 70:87-93.

Loiselle, M. C., C. Ster, B. G. Talbot, X. Zhao, G. F. Wagner, Y. R. Boisclair, and P. Lacasse. 2009. Impact of postpartum milking frequency on the immune system and the blood metabolite concentration of dairy cows. J. Dairy Sci. 92:1900-1912.

McNamara, S., J. J. Murphy, F. P. O'Mara, M. Rath, and J. F. Mee. 2008. Effect of milking frequency in early lactation on energy metabolism, milk production and reproductive performance of dairy cows. Livest. Sci. 117:70-78.

NRC. 2001. Nutrient Requirements of Dairy Cattle. 7th rev. ed. Natl. Acad. Sci., Washington, DC.

Patton, J., D. A. Kenny, J. F. Mee, F. P. O'Mara, D. C. Wathes, M. Cook, and J. J. Murphy. 2006. Effect of milking frequency and diet on milk production, energy balance, and reproduction in dairy cows. J. Dairy Sci. 89:1478-1487.

Pearson, R. E., L. A. Fulton, P. D. Thompson, and J. W. Smith. 1979. Three times a day milking during the first half of lactation. J. Dairy Sci. 62:1941-1950.

Plaut, K., D. E. Bauman, N. Agergaard, and R. M. Akers. 1987. Effect of exogenous prolactin administration on lactational performance of dairy cows. Domest. Anim. Endocrinol. 4:279-290.

Poole, D. A. 1982. The effects of milking cows three times daily. Anim. Prod. 34:197-201.

Sanders, A. H. 2000. The effects of six times a day milking in early lactation on milk yield, milk composition, body condition, and reproduction. MS Thesis. Univ. of Maryland, College Park.

SAS Institute. 2003. JMP. User's Guide: Statistical Discovery Software. Version 5. SAS Inst. Inc., Cary, NC.

Smith, J. W., L. O. Ely, W. M. Graves, and W. D. Gilson. 2002. Effect of milking frequency on DHI performance measures. J. Dairy Sci. 85:3526-3533.

Sorensen, A., M. Alamer, and C. H. Knight. 1998. Physiological characteristics of high genetic merit and low genetic merit dairy cows: A comparison. Page 4 in Proc. British Society Anim. Sci., Scarborough, UK. British Society of Animal Science Press, Midlothian, UK.

Stelwagen, K., and C. H. Knight. 1997. Effect of unilateral once and twice daily milking of cows on milk yield and udder characteristics in early and late lactation. J. Dairy Res. 64:487-494.

VanBaale, M. J., D. R. Ledwith, J. M. Thompson, R. Burgos, R. J. Collier, and L. H. Baumgard. 2005. Effect of increased milking frequency in early lactation with or without recombinant bovine somatotropin. J. Dairy Sci. 88:3905-3912.

Wall, E. H., H. M. Crawford, S. E. Ellis, G. E. Dahl, and T. B. McFadden. 2006. Mammary response to exogenous prolactin or frequent milking during early lactation in dairy cows. J. Dairy Sci. 89:4640-4648.

Wall, E. H., and T. B. McFadden. 2008. Use it or lose it: Enhancing milk production efficiency by frequent milking of dairy cows. J. Anim. Sci. 86:27-36.

Waterman, D. F., R. J. Harmon, R. W. Hemken, and B. E. Langlois 1983. Milking frequency as related to udder health and milk production. J. Dairy Sci. 66:253-258.

Wilde, C. J., C. V. P. Addey, L. M. Boddy, and M. Peaker. 1995. Autocrine regulation of milk secretion by a protein in milk. Biochem. J. 305:51-58.

Wildman, E. E., G. M. Jones, P. E. Warner, R. L. Boman, H. F. Troutt Jr., and T. N. Lesch. 1982. A dairy cow body condition scoring system and its relation to selected production characteristics. J. Dairy Sci. 65:495-501. 